\title{
Leptin, ghrelin and calprotectin: inflammatory markers in childhood asthma?
}

\author{
Nazan Cobanoglu*, Nilufer Galip², Ceyhun Dalkan³ and Nerin Nadir Bahceciler ${ }^{2}$
}

\begin{abstract}
Background: Appetite-modulating hormones ghrelin and leptin might be relevant to asthma with their pro-inflammatory effects, and calprotectin has been recognized as a promising marker of inflammation. The purpose of this study was to explore whether asthma, atopy and lung functions has a relation with serum levels of leptin, ghrelin and calprotectin as inflammatory markers in children.

Methods: A cross-sectional study was performed by searching the doctor diagnosed asthma through questionnaires filled in by parents who were phoned, and children were invited to supply fasting blood samples in order to measure serum levels of leptin, ghrelin and calprotectin, and to perform skin prick test and spirometry. Participants were divided into Group 1, children with previous diagnosis of asthma, and Group 2, children without previous diagnosis of asthma.
\end{abstract}

Results: One thousand and two hundred questionnaires were distributed and 589 of them were returned filled in. Out of 74 children whose parents accepted to participate in the study, 23 were in Group 1 and 51 were in Group 2. There was no statistical difference in serum levels of leptin, ghrelin, calprotectin, forced expiratory volume in one second ( $\left(\mathrm{FV}_{1)}\right.$, forced vital capacity (FVC), peak expiratory flow (PEF), forced expiratory flow between 25 and $75 \%$ of vital capacity $\left(\mathrm{FEF}_{25-75}\right.$ ) values, and skin prick test results between the two groups ( $p$ values are $0.39,0.72$, $0.5,0.17,0.5,0.27,0.18$, and 0.81 respectively).

Conclusion: In this study the inflammation in asthmatic children could not be shown by using serum leptin, ghrelin and calprotectin levels and this is possibly due to the low number of children with ever asthma and equal skin prick test positivity in both groups. This study is the first study aimed to show the relation between serum calprotectin levels and inflammation in asthma. As this study was a cross-sectional study, further prospectively designed randomized controlled studies are necessary to show the association of these markers and inflammation in asthma.

Keywords: Asthma, Calprotectin, Ghrelin, Inflammation, Leptin

\section{Background}

Asthma is a chronic inflammatory condition of the airways associated with airway hyper-responsiveness that leads to recurrent episodic of airflow obstruction within the lungs. Although the cause of childhood asthma has not been definitely determined, current research includes a combination of environmental respiratory exposures, such as inhaled allergens, respiratory viral infections, air pollutants, and genetic vulnerabilities.

\footnotetext{
* Correspondence: drncobanoglu@yahoo.com

${ }^{1}$ Department of Pediatric Pulmonology, Near East University, Faculty of Medicine, Nicosia, North Cyprus

Full list of author information is available at the end of the article
}

Both the human and murine studies showed that the pro-inflammatory effects of recently discovered appetitemodulating hormones ghrelin and leptin might be relevant to asthma [1-3]. Both hormones have some immunomodulatory effects and counteract each other with regard to the production of pro-inflammatory cytokines such as TNF- $\alpha$ and IL- $1 \beta$ on human lymphocytes in vitro [4]. On the other hand, inflammation decreases serum ghrelin levels [5] and increases serum leptin levels [6]. Calprotectin has been recognized as a promising marker of inflammation $[7,8]$. The serum level of calprotectin may be a very sensitive non-specific inflammatory marker in various clinical settings and has been proposed for the

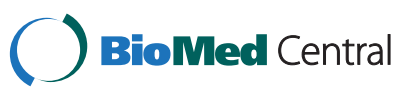


diagnosis of many inflammatory conditions [9]. To date it has not been searched whether serum calprotectin levels with leptin and ghrelin levels could be used to detect the inflammation related to childhood asthma. The purpose of this study therefore was to explore whether asthma, atopy and lung functions have a relation with serum levels of leptin, ghrelin and calprotectin as inflammatory markers in children.

\section{Methods}

A cross-sectional study was performed from May 1 to September 1, 2011, in summer time, among the first to fifth grade students of a randomly selected primary school in Nicosia. The investigation was coordinated by Near East University Faculty of Medicine Department of Paediatrics and approved by the Ethics Committee of this faculty. The International Study of Asthma and Allergies in Childhood (ISAAC) questionnaire, translated into Turkish previously [10], was distributed to all students to be filled in by their parents and returned to school. Then all responders were phoned, given information about the study and their children were invited to participate in this study. Children with any chronic disease and acute infection were excluded from the study. After obtaining written informed consents from their parents, fasting blood samples of participant children were drawn to measure serum leptin, ghrelin and calprotectin levels. Body mass indexes (BMI) of the children were calculated as weight $(\mathrm{kg}) /$ height $^{2}(\mathrm{~m})$. Skin prick test to aeroallergens and spirometry were performed to all participant children. Children were divided into two groups according to the responses to the question in ISAAC questionnaire "Has your child ever been diagnosed in asthma?" children were divided into two groups: group 1 included the children with previous diagnosis of asthma, while group 2 those children without previous diagnosis of asthma. The data of these two groups were compared.

\section{Laboratory procedures}

All laboratory investigations were performed by a researcher unaware of the asthma diagnosis of the children. Five $\mathrm{mL}$ samples of peripheral venous blood samples were obtained from all children. Each blood sample was left to coagulate for 30 minutes, then centrifuged for 15 minutes at $10000 \mathrm{rpm}$ and the extracted serum was collected and stored at $-20^{\circ} \mathrm{C}$ until analysis.

Leptin $(\mathrm{ng} / \mathrm{mL})$ and ghrelin $(\mathrm{ng} / \mathrm{mL})$ were measured by EIA ( DRG Diagnostics, Inc., Marburg, Germany and Raybiotech, Inc., GA, USA respectively), whereas caprotectin $(\mathrm{ng} / \mathrm{mL}$ ) was measured by ELISA (Human Calprotectin ELISA kit, Cusabio Biotech, China) in serum samples. The methods of measurement were carried out according to the manufacturer instructions. The standard curves are created by reducing the date using computer software (Softmax Pro.) capable of generating four parameter logistic (4PL) curve-fit. The lower detection limits were $1 \mathrm{ng} / \mathrm{mL}$ for leptin, $161 \mathrm{pg} / \mathrm{mL}$ for ghrelin, and $2 \mathrm{ng} / \mathrm{mL}$ for calprotectin. The values under lower detection limits were accepted as $0 \mathrm{ng} / \mathrm{mL}$.

\section{Skin prick test}

Skin prick tests to aeroallergens were performed by a researcher unaware of the asthma diagnosis of the children with 24 common aeroallergens belonging to 5 groups; mites (Dermatophagoides farinae, Dermatophagoides pteronyssinus), molds (Alternaria, Aspergillus mix, Penicillium mix, Candida albicans), pollens (Betulaceae, Aesculus Hippo, Olea Europea, Plantago, Artemisia, Parietaria, Secale cereale, Triticum vulgaris, Zea mays, mixture of 5 grasses), animal epithelia (feathers mixture [duck, goose and hen], cat hair, dog hair) and insects (cockroach) (Stallergenes, Antony, France). Histamine and saline were used as positive and negative controls, respectively. A drop of each allergen extract was placed on the volar surface of the left forearm and was penetrated with a stallerpoint. After 15 minutes, the wheal reaction was measured as the mean of the longest diameter and the diameter perpendicular to it. A wheal diameter of at least $3 \mathrm{~mm}$ greater than those of the negative controls was considered as positive.

\section{Lung function testing}

Lung function was assessed with a spirometer (Vmax Encore 22, California, USA). At least three reproducible blows with maximum difference between two best measurements of $5 \%$ or $150 \mathrm{ml}$ were obtained and the highest value of these three attempts was accepted. Measurements of forced expiratory volume in one second $\left(\mathrm{FEV}_{1}\right.$ ), forced vital capacity (FVC), peak expiratory flow (PEF) and forced expiratory flow between 25 and $75 \%$ of vital capacity $\left(\mathrm{FEF}_{25-75}\right)$ were compared to normal values, standardized for gender, height and age, and were expressed as a percentage of the predicted value.

\section{Statistical analysis}

The Pearson chi-square test was performed in the case of categorical variables. Mean \pm SD values were calculated for normally distributed data and median values for non-normally distributed data. Unpaired ttests were used to test differences between groups for normally distributed variables. The Mann-Whitney U-test and Spearman's rho test were used for nonparametric variables. $\mathrm{p} \leq 0.05$ was considered statistically significant. Statistical analyses were performed by using the SPSS software package for Windows (release 17.0.0; SPSS Inc., Chicago, Ill, USA). 


\section{Results}

One thousand and two hundred ISAAC questionnaires were distributed and 580 of them returned filled in. Parents of 74 children accepted to participate in the study following the invitation and the74 children (23 in Group 1 and 51 in Group 2) were recruited to the study. There was no statistical difference in serum levels of leptin, ghrelin, calprotectin, $\mathrm{FEV}_{1}$, FVC, PEF, $\mathrm{FEF}_{25-75}$ values, and skin prick test results between the two groups ( $\mathrm{p}$ was $0.39,0.72$, $0.5,0.17,0.5,0.27,0.18$, and 0.81 respectively). Data are presented in Table 1. Serum levels of leptin, ghrelin and calprotectin were also compared after dividing children into two new groups according to the results of skin prick tests: "Skin prick test positive" (SPT+) $(\mathrm{n}=47)$ and "Skin prick test negative" (SPT-) $(\mathrm{n}=24)$, and again there was no statistically significant difference between the two groups. Data are presented in Table 2.

There was a significant correlation between BMI and serum leptin levels $(\mathrm{p}<0.001$ and correlation coefficient $=$ 0.85) (Figure 1) of all participants, but not between BMI and serum ghrelin and calprotectin levels ( $\mathrm{p}$ values are 0.27 and 1.0, correlation coefficients are 0.12 and 0.00 respectively).

\section{Discussion}

In this cross-sectional study, no differences in serum levels of leptin, ghrelin and calprotectin were detected between children with and without a previous diagnosis of asthma according to ISAAC questionnaire.

Previously, a growing number of studies have examined the potential role of leptin in the respiratory system. Although leptin is synthesized and secreted mainly by white adipose tissue [11], accumulative data have identified foetal and adult lung tissue as leptin responsive and producing organs. Also, leptin's involvement in pulmonary homeostasis has become increasingly evident [12-15]. Leptin and leptin receptors are expressed by the lung $[12,16]$. Besides its proinflammatory systemic effects, leptin negatively modulates the function of regulatory $\mathrm{T}$ cells that are associated with asthma [17], and promote Th1 proliferation with increased production of interferon- $\gamma[18,19]$. Recent in vitro studies indicate that leptin also stimulates release of vascular endothelial growth factor by airway smooth muscle cells [20], although it does not affect airway smooth muscle cell proliferation [13]. Vascular endothelial growth factor may stimulate subepithelial neovascularization and vascular permeability, a key finding in asthma [20]. In vitro studies have documented that leptin can significantly up-regulate the cell surface expression of intracellular adhesion molecule ICAM-1 and CD18 and suppress those of ICAM-3 and L-selectin in eosinophils [21], while it augments alveolar macrophage leukotriene synthesis [22]. The latter results suggest that leptin may induce accumulation of eosinophils and may enhance inflammatory processes at sites such as the lung or the airways, thereby increasing to some extent allergic airway responses $[21,22]$. A causal role for leptin in asthma is supported by murine studies: the administration of exogenous leptin in leptin-deficient mice augments airway hyperreactivity following allergen challenge, as well as lung inflammation following ozone exposure [1,23]. Human data are, however, currently inconclusive regarding the independent association between serum leptin concentration and risk of asthma $[3,24,25]$. A large population-based study by Jartti et al. [26] used a sequential nested case control study design set within an established Finnish cohort and did not show an independent association between asthma and serum leptin concentrations. Some children studies with

Table 1 Comparison of BMI, gender, age, serum levels of leptin, ghrelin and calprotectin levels, lung function and skin prick tests in asthmatic and non-asthmatic children

\begin{tabular}{|c|c|c|c|}
\hline & Group $1(n=23)$ & Group $2(n=51)$ & $\mathrm{p}$ value \\
\hline BMI (mean \pm SD) & $20.3 \pm 4.4$ & $19.1 \pm 4.2$ & 0.82 \\
\hline Gender (girl)(n)(\%) & $9(39 \%)$ & $31(60 \%)$ & 0.08 \\
\hline Age (year) $($ mean \pm SD) & $8.2 \pm 1.2$ & $8.8 \pm 1.4$ & 0.09 \\
\hline Leptin (ng/mL) (median [minimum-maximum]) & $5.3(0.4-27.4)$ & $8.8(0.3-31.3)$ & 0.39 \\
\hline Ghrelin (ng/mL) (median [minimum-maximum]) & $30.9(1.9-138.5)$ & $26.9(1.0-436.3)$ & 0.72 \\
\hline Calprotectin $(\mathrm{ng} / \mathrm{mL}$ ) (median [minimum-maximum]) & $1.0(0.0-106.8)$ & $1.5(0.0-27.5)$ & 0.5 \\
\hline $\mathrm{FEV}_{1} \%$ (median [minimum-maximum]) & $107(76-126)$ & $101(79-130)$ & 0.17 \\
\hline FVC\% (median [minimum-maximum]) & $99(73-121)$ & $97(36-173)$ & 0.5 \\
\hline PEF\% (median [minimum-maximum]) & $99(72-126)$ & $96(78-126)$ & 0.27 \\
\hline $\mathrm{FEF}_{25-75} \%$ (median [minimum-maximum]) & $111(39-177)$ & $95(65-129)$ & 0.18 \\
\hline Skin prick test positive (n) (\%) & $32(65 \%)$ & $15(68 \%)$ & 0.81 \\
\hline
\end{tabular}

BMI body mass index, $F E F_{25-75}$ forced expiratory flow between 25 and $75 \%$ of vital capacity, $F E V_{1}$ forced expiratory flow in one second, $F V C$ forced vital capacity, PEF peak expiratory flow. 
Table 2 Comparison of serum levels of leptin, ghrelin and calprotectin levels according to the skin prick test results

\begin{tabular}{lccc}
\hline & SPT $+(\mathbf{n}=\mathbf{4 7})$ & SPT- $(\mathbf{n}=\mathbf{2 4})$ & p value \\
\hline Leptin $(\mathbf{n g} / \mathbf{m L})$ (median [minimum-maximum]) & $5.2(0.2-27.5)$ & $5.7(0.8-20.9)$ & 0.92 \\
Ghrelin $(\mathbf{n g} / \mathbf{m L})($ median $[$ minimum-maximum]) & $30.9(1.9-138.5)$ & $26.9(1.0-436.3)$ & 0.98 \\
Calprotectin $(\mathbf{n g} / \mathbf{m L})$ (median [minimum-maximum]) & $1.0(0.0-19.4)$ & $0.5(0.0-106.8)$ & 0.62 \\
\hline
\end{tabular}

SPT+, Skin prick test positive, SPT-, Skin prick test negative.

significantly smaller sample sizes showed a positive association [3,24], while others not [27]. In our cross-sectional study, we also did not show an correlation between asthma (both according to self declaration of doctor diagnosed asthma or to the results of skin prick tests) and serum leptin concentration.

Undoubtedly, leptin has emerged in the literature as a multifunctional hormone with versatile activities and complex counteractions with other cytokines and adipokines. However, decoding its pulmonary impact is not an easy task, since the role of leptin cannot always be separated from obesity and the biology of adipose tissue. Recent epidemiological studies have demonstrated that the prevalence of asthma and obesity are both increasing concomitantly, suggesting that these factors may be causally related [28]. Accumulating evidence has implicated systemic changes in immune function in the development of obesity; several obesity-related hormones and cytokines may lead to airway hyper-responsiveness $[1,29,30]$. In our study there was no difference between the BMIs of asthmatic and nonasthmatic children, so we could eliminate the effect of obesity on the serum levels of leptin.

In the present study, we paid special attention to the recently discovered hormones ghrelin and leptin, because both hormones seem to exert a wide range of effects on the immune system [4,31]. It has been reported that ghrelin dose-dependently inhibits proliferation of antiCD3-activated murine $\mathrm{T}$ cells and non-specifically inhibits both T-helper 1 (Th1; IL-1 and IFN- $\gamma$ ) and Th2 (IL-4 and IL-19) cytokine mRNA expression [32]. In a previous study on children, Matsuda et al. [2] showed a significant correlation between the levels of plasma ghrelin and leptin levels and BMI. They found that overweight children had significantly higher IgE concentrations than non-obese children, and also observed significant correlation between serum IgE and plasma concentrations of ghrelin and leptin. These findings suggested the possibility that obesity-related hormones may represent a link between obesity and allergic disorders. Nevertheless, Okamatsu et al. [33] found that serum leptin had a significant positive correlation with BMI while plasma ghrelin did not correlate with it. Surprisingly, a significant inverse correlation between plasma concentrations of ghrelin and serum immunoglobulin concentrations was found in their study. In the present study, we did not find a difference between the serum ghrelin levels of asthmatic and non-asthmatic children, and there was no correlation between serum ghrelin levels and BMI in the whole group.

Elevated serum calprotectin (synonyms in the literature: aka MRP8/14, calgranulin, cystic fibrosis-associated antigen, and S100) levels are found in a variety of chronic inflammatory conditions, including rheumatoid arthritis, allograft

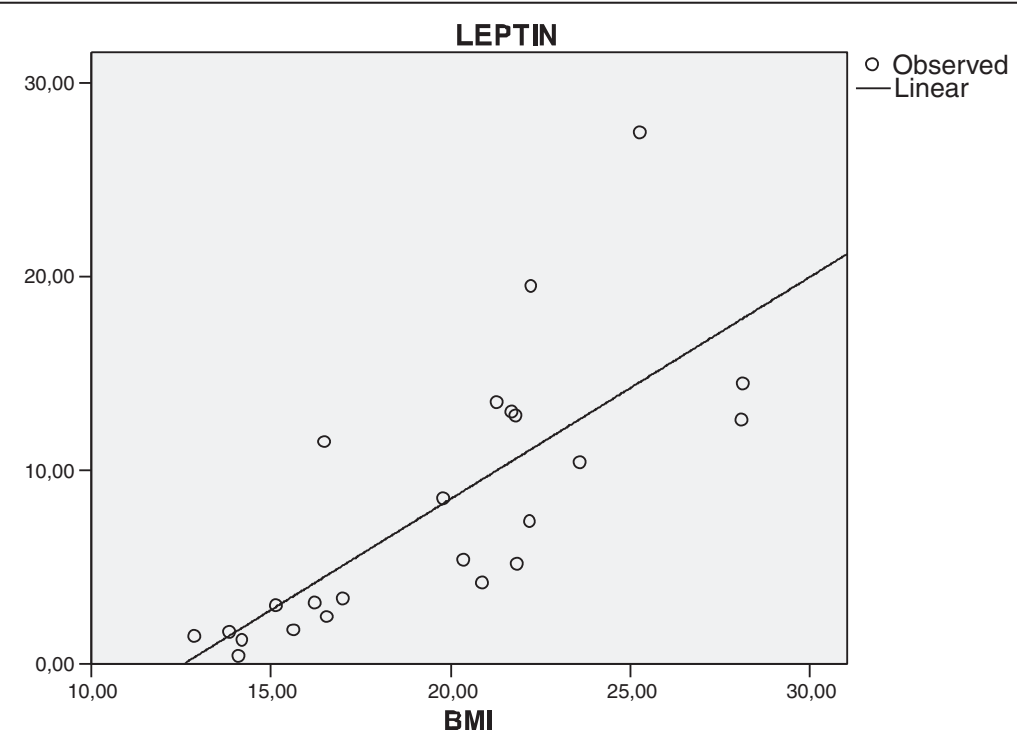

Figure 1 Correlation between the serum levels of leptin and BMI in all participant children. $(p<0.001$ and correlation coefficient $=0.85)$ 
rejections, inflammatory bowel and lung diseases, and environmental tobacco smoke-exposure [34]. Asthma is a chronic inflammatory disease, therefore we compared the serum calprotectin levels of asthmatic and non-asthmatic children demonstrating no significant difference between the two groups. Possibly, we could not detect any difference between groups due to the low number of children with asthma. In addition, skin prick test positivity was equal in both groups, and this might be another reason why no differences were detected between two groups. It could be better to include children with current diagnosis of asthma rather than responses to questionnaires.

There were no statistically significant differences in terms of spirometric data and skin prick test results between the two groups. Because our study was based on a screening questionnaire only, it could be that, absence of current asthma and therefore allergic inflammation in some of the children at the time of study might have influenced the results. Possibly, monitoring inflammatory markers during exacerbations of asthma could be more useful.

Although we could not find any statistical difference between the two groups in terms of serum levels of leptin, there was a significant correlation between BMI and serum leptin levels. As leptin is synthesized and secreted mainly by white adipose tissue this correlation was rational and compatible with previous studies.

\section{Conclusions}

It is indisputable that asthma is an inflammatory condition although we could not show the inflammation by using serum leptin, ghrelin and calprotectin levels in asthmatic children. According to the current literature, this is the first study aimed to show the association of serum calprotectin with asthma. As our study was a cross-sectional study, further prospectively designed randomized controlled studies are necessary in order to show the association between these markers and inflammation in asthma.

\section{Competing interests}

The authors declared that they have no competing interests.

\section{Authors' contributions}

NC participated in the design of the study, performed statistical analysis and drafted the manuscript. NG and CD participated in coordination and helped to draft the manuscript. NNB participated in the design of the study and helped to draft the manuscript.

\section{Author details}

'Department of Pediatric Pulmonology, Near East University, Faculty of Medicine, Nicosia, North Cyprus. ${ }^{2}$ Department of Pediatric Allergy and Immunology, Near East University, Faculty of Medicine, Nicosia, North Cyprus. ${ }^{3}$ Department of Pediatrics, Near East University, Faculty of Medicine, Nicosia, North Cyprus.

Received: 16 April 2013 Accepted: 6 August 2013

Published: 25 September 2013

\section{References}

1. Shore SA, Schwartzman IN, Mellema MA, Flynt L, Imirich A, Johnston RA: Effect of leptin on allergic airway responses in mice. J Allergy Clin Immunol 2005, 115:103-109.

2. Matsuda K, Nishi Y, Okamatsu Y, Kojima M, Matsuishi T: Ghrelin and leptin: a link between obesity and allergy? J Allergy Clin Immunol 2006, 117:705-706

3. Guler N, Kirerleri E, Ones U, Tamay Z, Salmayenli N, Darendeliler F: Leptin: does it have any role in childhood asthma? J Allergy Clin Immunol 2004, 114:254-259.

4. Dixit VD, Schaffer EM, Pyle RS, Collins GD, Sakthivel SK, Palaniappan R, Lillard JW Jr, Taub DD: Ghrelin inhibits leptin- and activation induced proinflammatory cytokine expression by human monocytes and T cells. J Clin Invest 2004, 114:57-66.

5. Striz I, Trebichavsky I: Calprotectin-a pleiotropic molecule in acute and chronic inflammation. Physiol Res 2004, 53:245-253.

6. Danesh J, Wheeler JG, Hirschfield GM, Eda S, Eiriksdottir G, Rumley A, Lowe $\mathrm{GD}$, Pepys MB, Gudnason V: C-reactive protein and other circulating markers of inflammation in the prediction of coronary heart disease. N Engl J Med 2004, 350:1387-1397.

7. Foell D, Roth J: Proinflammatory $\mathrm{S} 100$ proteins in arthritis and autoimmune disease. Arthritis Rheum 2004, 50:3762-3771.

8. Healy AM, Pickard MD, Pradhan AD, Wang Y, Chen Z, Croce K, Sakuma M, Shi C, Zago AC, Garasic C, Damokosh Al, Dowie TL, Poisson L, Lillie J, Libby P, Ridker PM, Simon DI: Platelet expression profiling and clinical validation of myeloid-related protein-114 as a novel determinant of cardiovascular events. Circulation 2006, 113:2278-2284

9. Croce K, Gao H, Wang Y, Mooroka T, Sakuma M, Shi C, Sukhova GK, Packard RR, Hogg N, Libby P, Simon DI: Myeloid-related protein-8/14 is critical for the biological response to vascular injury. Circulation 2009, 120:427-436.

10. Ones U, Sapan N, Somer A, Disci R, Salman N, Guler N, Yalcin I: Prevalence of childhood asthma in Istanbul, Turkey. Allergy 1997, 52:570-575.

11. Friedman $J M$, Halaas $J \mathrm{~L}$ : Leptin and the regulation of body weight in mammals. Nature 1998, 395:763-770.

12. Bruno A, Pace E, Chanez P, Gras D, Vachier I, Chiappara G, La Guardia M, Gerbino S, Profita M, Gjomarkaj M: Leptin and leptin receptor expression in asthma. J Allergy Clin Immunol 2009, 124:230-237.

13. Nair P, Radford K, Fanat A, Janssen L, Peters-Golden M, Cox PG: The effects of leptin on airway smooth muscle responses. Am J Respir Cell Mol Biol 2008, 39:475-481.

14. Vernooy JH, Drummen NE, van Suylen RJ, Cloots RH, Möller GM, Bracke KR, Zurderduyn S, Dentener MA, Bruselle GG, Hiemstra PS, Wouters EF: Enhanced pulmonary leptin expression in patients with severe COPD and asymptomatic smokers. Thorax 2009, 64:26-32.

15. Tsuchiya T, Shimuzu H, Horie T, Mori M: Expression of leptin receptor in lung: leptin as a growth factor. Eur J Pharmacol 1999, 365:273-279.

16. Bergen HT, Cherlet TC, Manuel P, Scott JE: Identification of leptin receptors in lung and isolated fetal type II cells. Am J Respir Cell Mol Biol 2002, 27:71-77.

17. Taleb S, Herbin O, Ait-Oufella H, Verreth W, Gourdy P, Barateau V, Merval R, Esposito B, Clement K, Holvoet P, Tedgui A, Mallat Z: Defective leptin/leptin receptor signaling improves regulatory $T$ cell immune response and protects mice from atherosclerosis. Arterioscler Thromb VasC Biol 2007, 27:2691-2698.

18. Lord GM, Matarese G, Howard JK, Baker RJ, Bloom SR, Lechler I: Leptin modulates the T-cell immune response and reverses starvation-induced immunosupression. Nature 1998, 394:897-901.

19. Matarese G, La Cava A, Sanna V, Lord GM, Lechler Rl, Fontana S, Zappacosta S: Balancing susceptibility to infection and autoimmunity: a role for leptin? Trends Immunol 2002, 23:182-187.

20. Shin JH, Kim JH, Lee WY, Shim JY: The expression of adiponectin receptors and the effects of adiponectin and leptin on airway smooth muscle cells. Yonsei Med J 2008, 49:804-810

21. Wong CK, Cheung PF, Lam CW: Leptin-mediated cytokine release and migration of eosinophils: implications for immunopathophysiology of allergic inflammation. Eur J Immunol 2007, 37:2337-2348.

22. Mancuso P, Canetti C, Gottschalk A, Tithof PK, Peters-Golden M: Leptin augments alveolar macrophage leukotriene synthesis by increasing phospholipase activity and enhancing group IVC iPLA2 (cPLA2gamma) protein expression. Am J Physiol Lung Cell Mol Physiol 2004, 287:L497-L502. 
23. Shore SA, Rivera-Sanchez YM, Schwartzman IM, Johnston RA: Responses to ozone are increased in obese mice. J Appl Physiol 2003, 95:938-945.

24. Nagel G, Koenig W, Rapp K, Wabitsch M, Zoellner I, Weiland SK:

Associations of adipokines with asthma, rhinoconjunctivitis, and eczema in German schoolchildren. Pediatr Allergy Immunol 2009, 20:81-88.

25. Sood A, Ford ES, Camargo JA Jr: Association between leptin and asthma in adults. Thorax 2006, 61:300-305.

26. Jartti T, Saarikoski L, Jartti L, Lisinen I, Jula A, Huupponen R, Viikari J, Raitakari OT: Obesity, adipokines and asthma. Allergy 2009, 64:770-777.

27. Kim KW, Shin YH, Lee KE, Kim ES, Sohn MH, Kim KE: Relationship between adipokines and manifestations of childhood asthma. Pediatr Allergy Immunol 2008, 19:535-540.

28. Hancox RJ, Milne BJ, Poulton R, Taylor DR, Greene JM, McLachlan CR Cowan JO, Flannery EM, Herbison GP, Sears MR: Sex differences in the relation between body mass index and asthma and atopy in a birth cohort. Am J Respir Crit Care Med 2005, 171:440-445.

29. Shore SA, Fredberg JJ: Obesity, smooth muscle, and airway hyperresponsiveness. J Allergy Clin Immunol 2005, 115:925-927.

30. Sood A: Does obesity weigh heavily on the health of human airway? J Allergy Clin Immunol 2005, 115:921-924.

31. Tilg H, Moschen AR: Adipocytokines: mediators linking adipose tissue, inflammation and immunity. Nat Rev Immunol 2006, 6:772-783.

32. Xia Q, Pang W, Pan H, Zheng Y, Kang JS, Zhu SG: Effects of ghrelin on the proliferation and secretion of splenic T lymphocytes in mice. Regul Pept 2004, 122:173-178.

33. Okamatsu Y, Matsuda K, Hiramoto I, Tani H, Kimura K, Yada Y, Kakuma T, Higuchi S, Kojima M, Matsuishi T: Ghrelin and leptin modulate immunity and liver function in overweight children. Pediatr Int 2009, 51:9-13.

34. Roth J, Goebeler M, Sorg C: S100A8 and S100A9 in inflammatory diseases. Lancet 2001, 357:1041.

doi:10.1186/2049-6958-8-62

Cite this article as: Cobanoglu et al.: Leptin, ghrelin and calprotectin: inflammatory markers in childhood asthma?. Multidisciplinary Respiratory Medicine 2013 8:62.

\section{Submit your next manuscript to BioMed Central and take full advantage of:}

- Convenient online submission

- Thorough peer review

- No space constraints or color figure charges

- Immediate publication on acceptance

- Inclusion in PubMed, CAS, Scopus and Google Scholar

- Research which is freely available for redistribution 